MINERALOGIA, 45, No 1-2: 47-57 (2014)

Original paper

\title{
The fossil wood of East Cairo, Egypt: A mineralogical view
}

\author{
Kamaleldin M. HASSAN \\ Department of Radioactive Sedimentary Deposits, Research Sector, Nuclear Materials Authority, \\ P.O. Box 30, Maadi, Cairo, Egypt \\ egy100@yahoo.com
}

Received: March 4, 2015

Received in revised form: June 4, 2015

Accepted: June 8, 2015

Available online: June 30, 2015

\begin{abstract}
As part of the characterization of the petrified wood of East Cairo at the New Cairo Petrified Forest, representative samples collected from the area were studied by X-ray powder diffraction (XRD) and optical microscopy. The samples, as indicated by XRD analysis, are composed of quartz \pm some goethite \pm minor moganite \pm minor gypsum \pm trace calcite. The absence of moganite in some samples has been attributed to the transformation of moganite to quartz or to leaching processes. Under the optical microscope, some of the 10 petrified-wood samples are permineralized with mainly microcrystalline quartz (chalcedony), some with a combination of chalcedony and microgranular quartz, and some with microgranular quartz. The sequence of silicification is likely to have been either opaline precursor to chalcedony and quartz, or directly to chalcedony and quartz. The crystallinity indices (C.I.) of the quartz in the samples studied, measured using a standard X-ray powder diffraction procedure, are consistent with the petrographic findings. The chalcedonic samples have the least C.I. values, and the microgranular quartz samples the highest values.
\end{abstract}

Key-words: chalcedony, petrified wood, New Cairo, Egypt, quartz, crystallinity index, moganite

\section{Introduction}

Petrified wood is the result of a tree form having been completely permineralized through the replacement of the original material and the filling of the original pore spaces with mainly $\mathrm{SiO}_{2}$ (silica). Other minerals, such as hematite and goethite, often enter into solution with the silica during the petrification process. The progressive transformation of silica in petrified wood to more stable forms from a highly disordered amorphous opal 
(opal-A), to a disordered interlayering of tridymite and cristobalite (opal-CT) to microcrystalline quartz (chalcedony) and finally to granular quartz has become an accepted hypothesis (e.g. Scurfield, Segnit 1984). Two other forms of silica in petrified wood have been recorded: (1) opal C and (2) moganite (Hatipoğlu, Türk 2009). It is noteworthy that the coexistence of opal-CT and chalcedony in some silicified wood specimens from Colorado, USA conflicts with the hypothesis that chalcedonic petrified wood would result exclusively from the transformation of an opaline precursor (Mustoe 2008). In Colorado, both silica polymorphs appear to have formed independently, rather than by diagenetic transformation of an opaline parent material. Understanding the mineral composition and microscopic characteristics of fossil wood forms preserved in geological units is important both for the understanding of how wood becomes petrified (i.e. Sutherland 1994; Mustoe 2008) and for assessing changes to the rock environment.
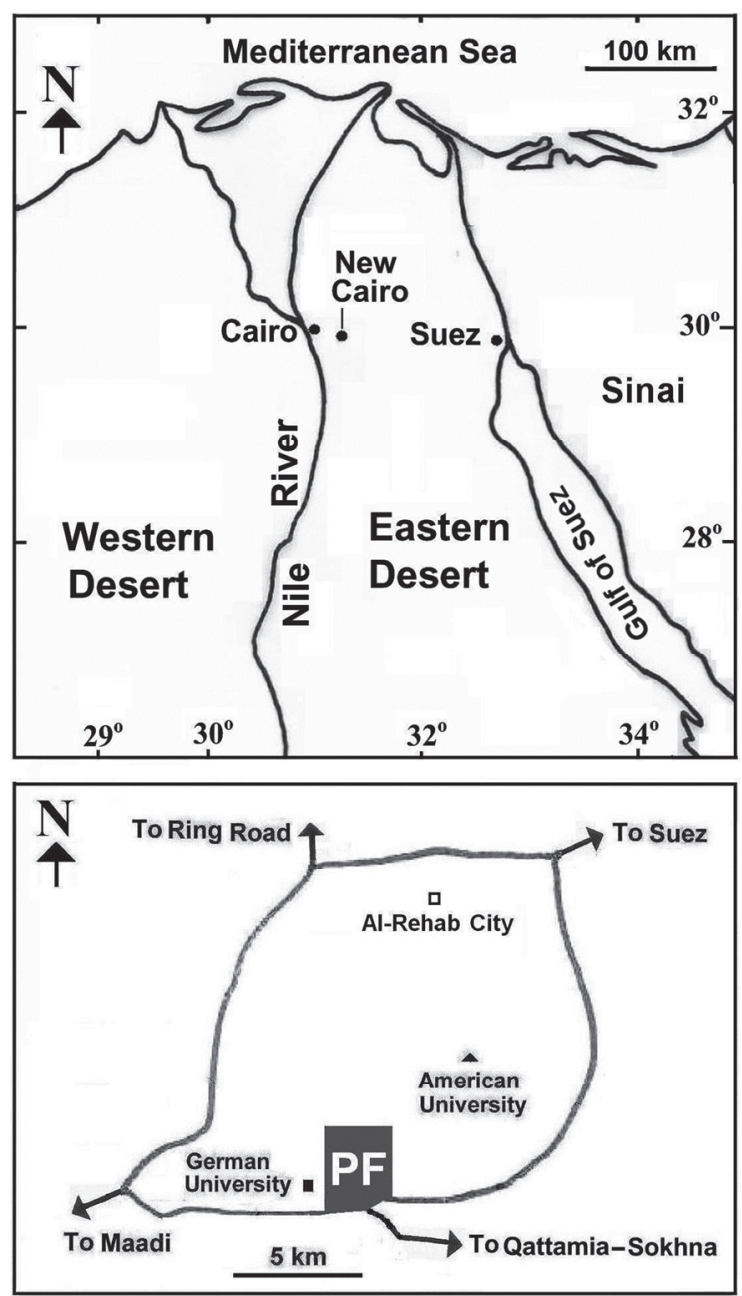

Fig. 1. Location of the Petrified Forest (PF) in New Cairo, Egypt. Modified from Hassan (2015b). 


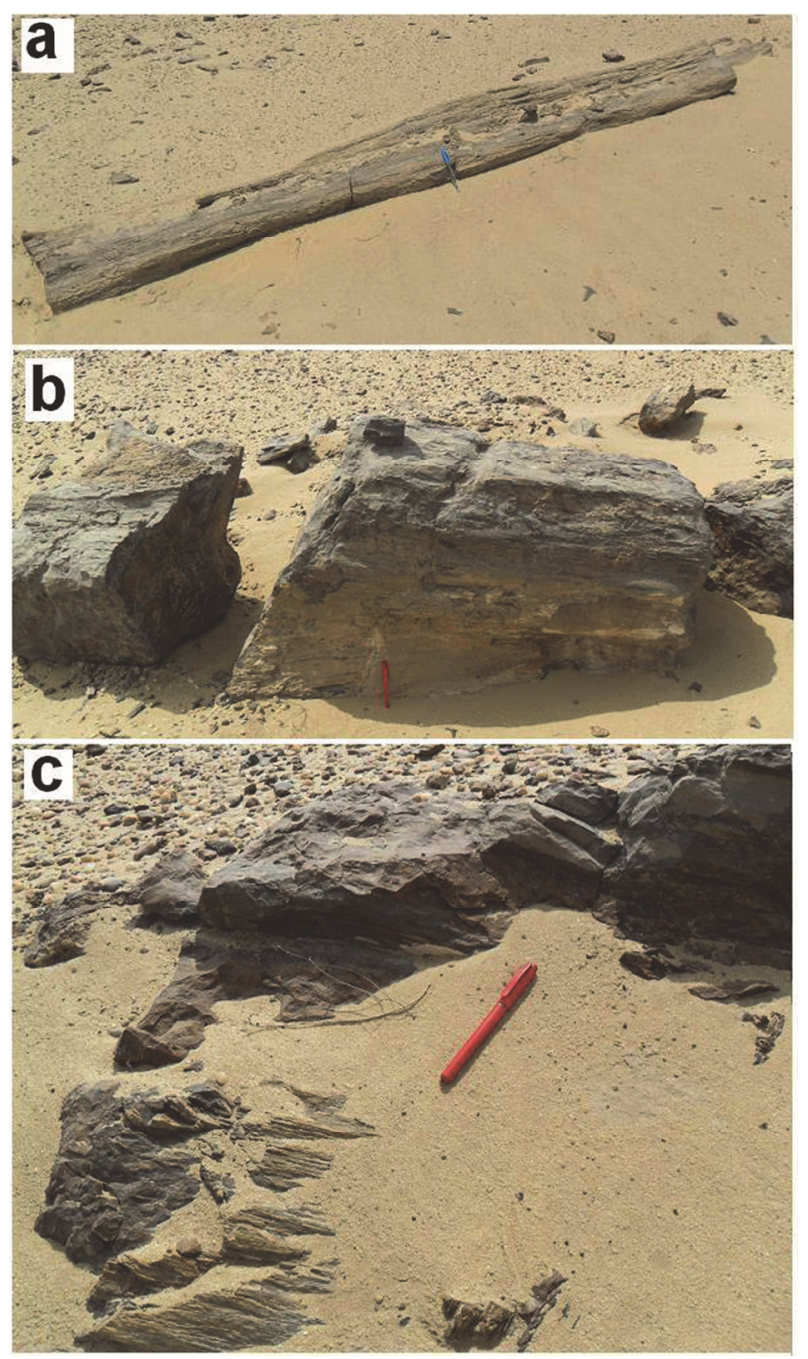

Fig. 2. Field photographs of stems (a, b) and a trunk (c) of fossilized trees of the New Cairo Petrified Forest $($ pen $=15 \mathrm{~cm})$.

The Petrified Forest of East Cairo (Fig. 1) covers a large area extending for tens of square kilometers from Quattamia, near Maadi in the Eastern Desert towards Suez. However, the official Petrified Forest site is the area of $\sim 6 \mathrm{~km}^{2}$ at 225-280 $\mathrm{m}$ elevation above sea level located in New Cairo between latitudes $31^{\circ} 26^{\prime} 53^{\prime \prime}-31^{\circ} 28^{\prime} 08^{\prime \prime}$ and

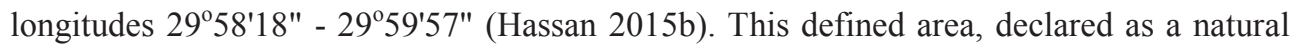
reserved site by government decree 944/1998, contains fossilized stumps and logs dominated by legume trees (El-Faramawi 2008; El-Saadawi et al. 2011). These silicified tree trunks, up to several meters in length, lie horizontally in an exposed section $<100 \mathrm{~m}$ thick of the late Eocene sands and gravels of the Maadi Formation (Fig. 2). The horizontal 
disposition, together with the absence of other plant organs (i.e. fossil twigs, branches, fruits), suggests extended transport prior to the tree trunks being silicified. Silicification occurred through the action of geysers after they settled where they now lie (Said 1962, 1990; El- Faramawi 2008). The present climate in the area is warm and dry in the summer and moderate with limited rainfall in the winter. The soils are dry and vegetation is limited to a few species of dry grasses and small shrubs (Hassan 2015b).

The elemental composition of the fossil wood at the New Cairo Petrified Forest varies (Table 1; Hassan 2015a). Average concentrations are (in wt \%): $\mathrm{SiO}_{2}=87.74, \mathrm{Fe}_{2} \mathrm{O}_{3}=8.82$, $\mathrm{Al}_{2} \mathrm{O}_{3}=0.44, \mathrm{MnO}=0.13, \mathrm{CaO}=0.25, \mathrm{Na}_{2} \mathrm{O}=0.07, \mathrm{P}_{2} \mathrm{O}_{5}=0.06, \mathrm{MgO}=0.05, \mathrm{~K}_{2} \mathrm{O}=$ $0.05, \mathrm{TiO}_{2}=0.002$. In the analysed samples, the organic carbon (OC) averages $0.008 \mathrm{wt} \%$ and loss on ignition (LOI) at $1000^{\circ} \mathrm{C}$ averages $2.49 \mathrm{wt} \%$ (Table 1). This weight loss is the result of loss of molecular water and hydroxyl groups from goethite and, to a lesser extent, from chacedoney and moganite.

TABLE 1

Whole-sample ICP-MS analyses, organic carbon (OC) and loss on ignition (LOI) for fossil wood from the New Cairo Petrified Forest, Egypt (Hassan 2015a).

\begin{tabular}{lllllll}
\hline $\begin{array}{l}\text { Samples } \\
\mathrm{wt} \%\end{array}$ & 1 & 2 & 3 & 4 & 5 & 6 \\
\hline $\mathrm{SiO}_{2}$ & 80.87 & 77.89 & 83.75 & 89.25 & 97.37 & 96.68 \\
$\mathrm{Al}_{2} \mathrm{O}_{3}$ & 0.33 & 0.92 & 0.23 & 0.38 & 0.58 & 0.21 \\
$\mathrm{TiO}_{2}$ & 0.004 & $<0.001$ & $<0.001$ & 0.002 & 0.002 & 0.001 \\
$\mathrm{Fe}_{2} \mathrm{O}_{3 \text { (total })}$ & 14.38 & 16.66 & 11.72 & 7.39 & 1.16 & 1.63 \\
$\mathrm{MgO}$ & 0.10 & 0.13 & 0.12 & 0.03 & 0.02 & 0.02 \\
$\mathrm{MnO}$ & 0.017 & 0.017 & 0.014 & 0.71 & 0.004 & 0.001 \\
$\mathrm{CaO}$ & 0.24 & 0.23 & 0.30 & 0.17 & 0.14 & 0.39 \\
$\mathrm{Na} 2 \mathrm{O}$ & 0.04 & 0.14 & 0.07 & 0.14 & 0.02 & 0.03 \\
$\mathrm{~K}_{2} \mathrm{O}$ & 0.06 & 0.04 & 0.05 & 0.04 & 0.05 & 0.03 \\
$\mathrm{P}_{2} \mathrm{O}_{5}$ & 0.06 & 0.08 & 0.05 & 0.15 & 0.01 & 0.01 \\
$\mathrm{LOI}$ & 3.90 & 3.90 & 3.70 & 1.90 & 0.65 & 1.0 \\
$\mathrm{OC}$ & 0.008 & 0.009 & 0.007 & 0.012 & 0.005 & 0.005 \\
\hline
\end{tabular}

Percentages of element oxides were determined by ICP-MS after acid digestion and LOI values by loss weight at $1000^{\circ} \mathrm{C}$. OC contents were determined with a Vario El Cube elemental analyzer. $\mathrm{The}^{\mathrm{SiO}_{2}}$ content of each sample was determined by: $\left[100-\left(\sum \% \mathrm{wt}\right.\right.$ element oxides $\left.\left.+\% \mathrm{wt} \mathrm{LOI}\right)\right]=\% \mathrm{wt} \mathrm{SiO}_{2}$.

For the present study, ten representative samples (S1-S10) of whole-rock petrified wood were collected from silicified stumps and logs at the Petrified Forest. The samples were fresh samples that had not been exposed to weathering; any weathered part was removed. The samples were analyzed by optical microscopy and X-ray diffraction. The samples are crypto- to fine grained, massive rock with variant colors (Fig. 3). 


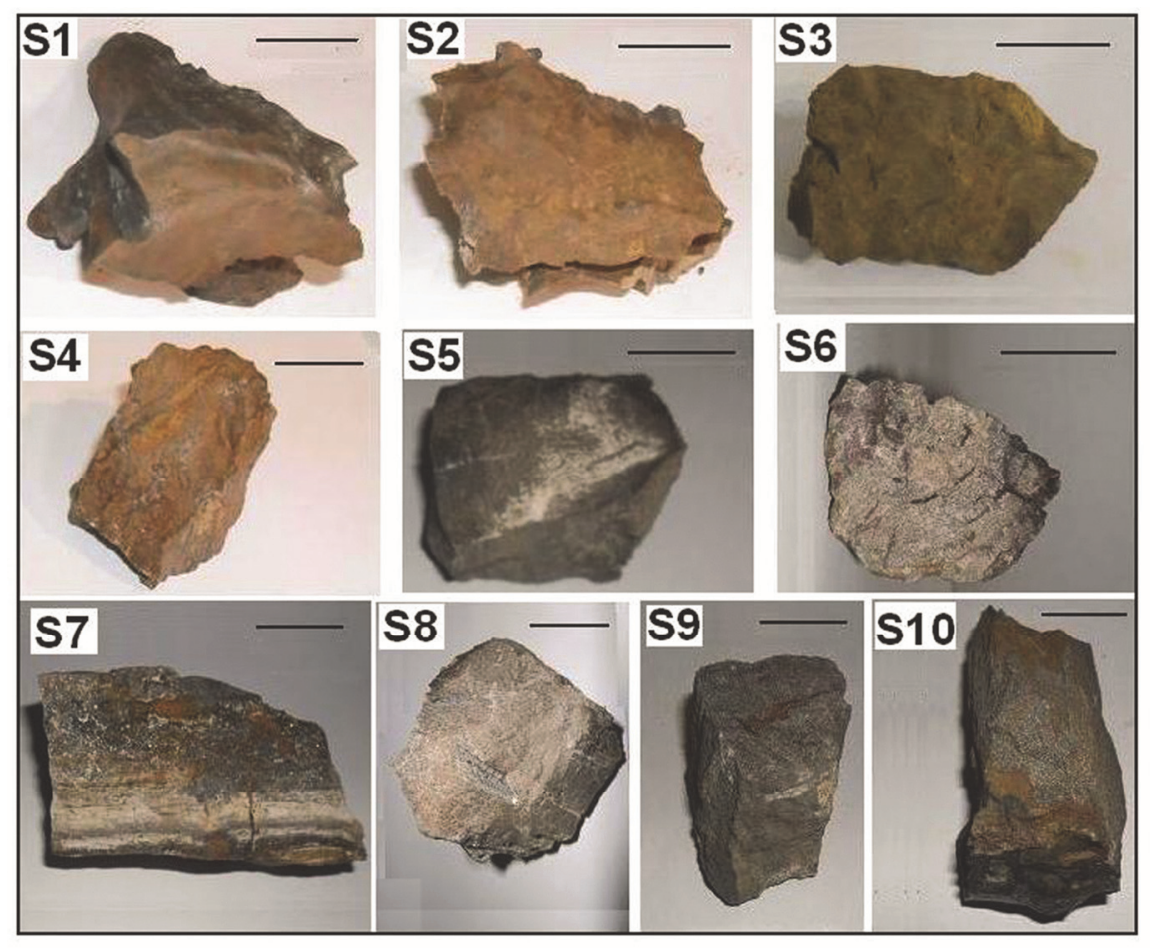

Fig. 3. Photographs of samples used in this study (scale bar $=5 \mathrm{~cm}$ ).

\section{Methods}

Thin sections of each sample were prepared at the Central Laboratory Sector of the Mineral Resources Authority, Cairo, Egypt. The thin sections were studied by conventional optical methods in transmitted- and reflected light using an Olympus BX41 polarizing microscope equipped with a digital camera at the Mineralogy Department of the Nuclear Materials Authority, Cairo, Egypt. For XRD analysis, portions of each sample were hand ground in copper containers and converted to powder, so that each analyzed aliquot represented an entire-averaged specimen. Powder samples were analyzed using a Rigaku Ultima IV diffractometer $(\mathrm{Cu}-\mathrm{K} \alpha$ radiation; a $2 \theta$ scanning rate $1 \% \mathrm{~min}$; step size of 0.04 , peak angle range $2-70^{\circ} 2 \theta$ ) at the School of Geology and Geophysics, University of Oklahoma, Norman, USA. The same was done for the standard material for this analysis, i.e. crystals of clean quartz. Mineral identification and pattern manipulation were conducted using MDI Jade 9 software.

\section{Results and Discussion}

Ten X-ray diffractograms (S1-S10) between $2-70^{\circ} 2 \theta$ with mineral identifications and percentages, and the quartz standard, are shown in Figure 4. In the samples, quartz is the 


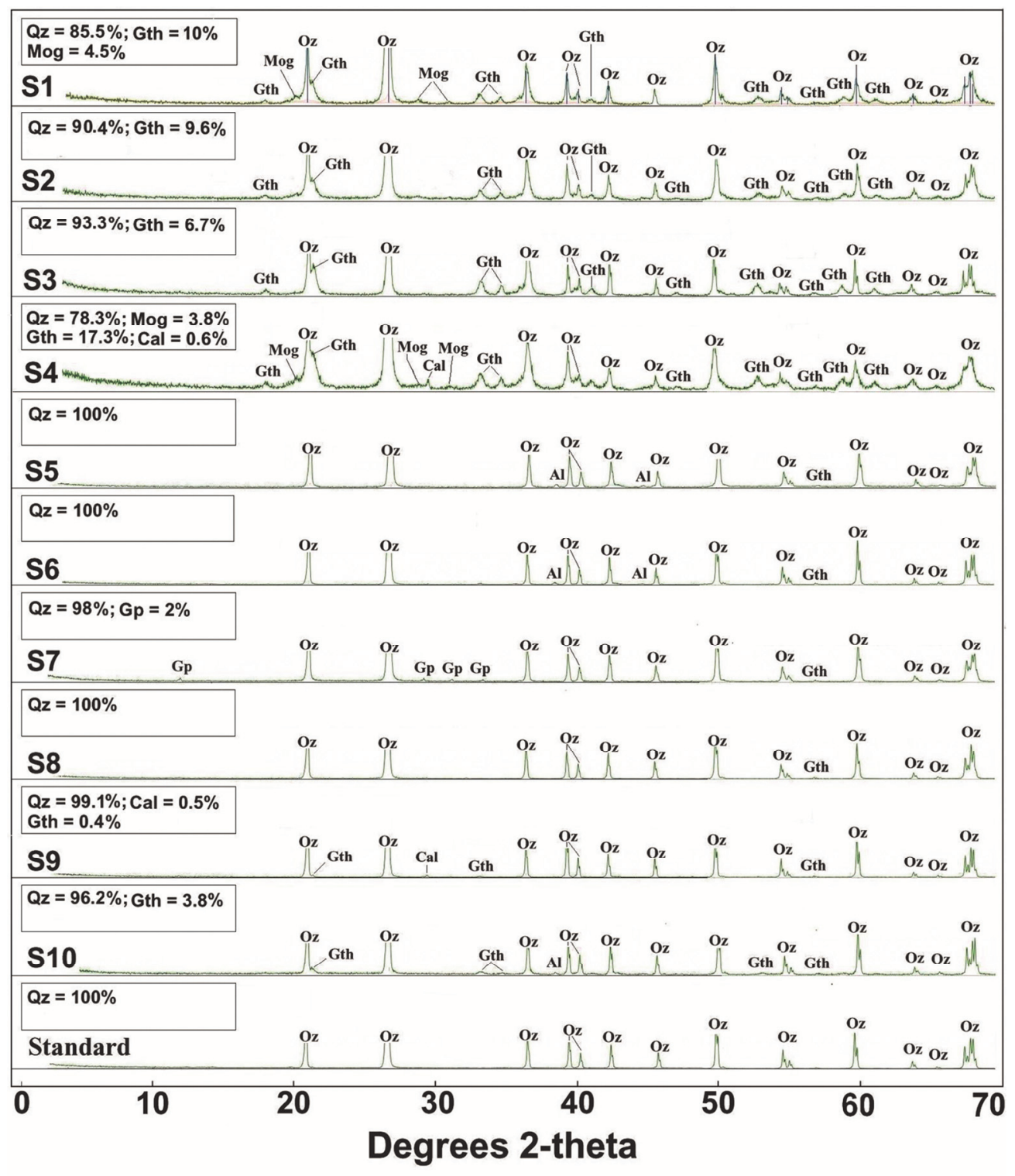

Fig. 4. XRD patterns of the samples (S1-S10) and quartz standard. Identified minerals are: aluminum (Al) from aluminum folder, Cal (calcite), Gypsum (Gp), goethite (Gth), moganite (Mog), quartz (Qz).

main component. Estimated quartz percentages range from $~ 78$ to $100 \%$. Goethite $(0.4-$ $17.3 \%$ ) occurs in only six samples, namely, S1-S4, S8 and S9. The goethite has broadened diffraction peaks, a feature that is characteristic of iron oxides in soils and other weathered environments (Hassan 2010; Hassan, Gunnlaugsson 2013). The overall difference in goethite content $(16.9 \%)$ may reflect local variations in the dissolved mineral content of 
groundwater. Another possibility is that the wood specimens had different degrees of permeability to goethite-bearing groundwater. Typically, iron is transported into plant tissues during the petrification process rather than accumulating during the life of the tree (Mustoe 2008).

Minor amounts of moganite $(<5 \%)$ were identified in S1 and S4, and of gypsum (2\%) in S7. Calcite $(<1 \%)$ occurs in trace amounts in S4. No clay or opaline minerals were detected in any of the samples. Moganite, a polymorph of quartz, is often found in microcrystalline quartz varieties: A large amount of this mineral was recorded by Heaney and Post (1992) in cherts from arid, alkaline environments. Those authors indicate that moganite is so prevalent in unaltered fine-grained silica samples that its absence in microcrystalline quartz varieties may be used as a measure of fluid-rock interaction. Here, the absence of moganite in the XRD patterns of the fossil wood samples other than S1 and S4 (Fig. 4) may suggest that either moganite readily recrystallizes to quartz in the presence of water, or that moganite has a higher solubility than quartz and had been leached out (Heaney, Post 1992).

The protocol in Murata and Norman (1976) was adopted as a standard X-ray diffraction procedure to quantify the degree of crystallinity of quartz in the samples, using a resolution of $1.3820 \AA\left(67.74^{\circ} 2 \theta\right)$ to calculate a crystallinity index (C.I.) for individual specimens. Index numbers are obtained by determining the peak height above background level for the $67.72^{\circ} 2 \theta(1.38 \AA$ d-spacing) diffraction peak measured for a powdered quartz crystal standard (Fig. 5). The standard is arbitrarily considered to have a C.I. index of 10; indices for the petrified wood samples ( $\mathrm{S} 1$ to $\mathrm{S} 10$ ) were calculated as ratios of their peak heights to this calibration standard. The C.I. range from 2.2-10.5 with an analytical error of $\pm 8 \%$ (two sigma) based on triplicate standard samples. Of the samples, S1 and S4 which contain minor amounts of moganite $(<5 \%)$, have the lowest C.I. values. The ten fossil wood specimens are composed of (microcrystalline quartz) chalcedony, often in porous fibrous aggregates, and/or micro-granular quartz (Fig. 6). Samples S1 and S4 are mainly chalcedony occurring as tiny, radiating fibers at the centers of relict cells (Fig. 6a, b). Intergrowths of chalcedony and goethite fibers are also evident in S4. Samples S2, S3 and S5-8, on the other hand, consist of fan-like quartz in a fine chalcedony matrix (Fig. 6c). Unlike the other samples, S9 and S10 consist entirely of micro-granular quartz (Fig. 6d). The petrography of the ten fossil wood samples is consistent with the X-ray mineralogy; the chalcedonic samples (S1 and S4) have the lowest crystalinity index values for quartz, and the microgranular quartz samples (S9 and S10) the highest values (see Fig. 5).

Siliceous volcanic rocks are a likely source of dissolved silica for wood petrification (Murata 1940; Mustoe 2008). At this location, the abundance of silica dust within the Maadi Formation at the New Cairo Petrified Forest is the likely source. No other petrological sources of silica are nearby. Permineralization of wood by silica always begins with the amorphous form and transformation progresses into a thermodynamically stable crystalline state over many millions of years (Stein 1982). This is true in a general sense. The early-Eocene fossil wood from the New Cairo Petrified Forest shows only crystalline silica phases (chalcedony and microgranular quartz) without an opaline precursor. Thus, both the chalcedony and the quartz probably reflect a disequilibrium situation and could 


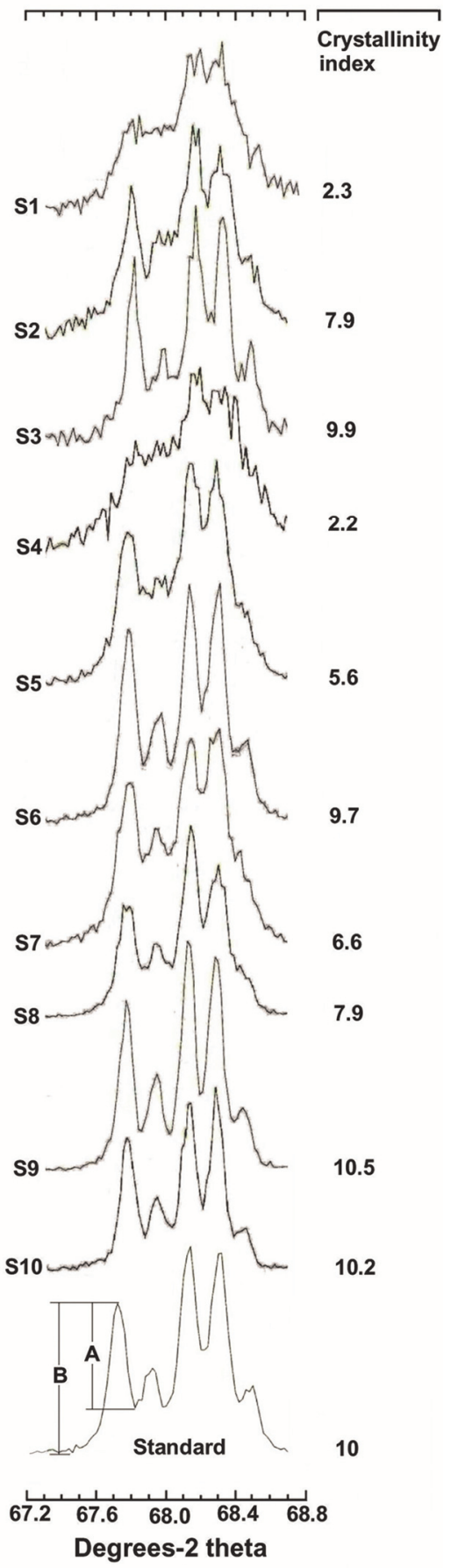

Fig. 5. Crystallinity index values for samples (S1-S10) calculated relative to the A/B ratio measured for the $67.72^{\circ} 2$-theta X-ray diffraction peak of a pure powdered quartz standard (see "Methods" for details). 


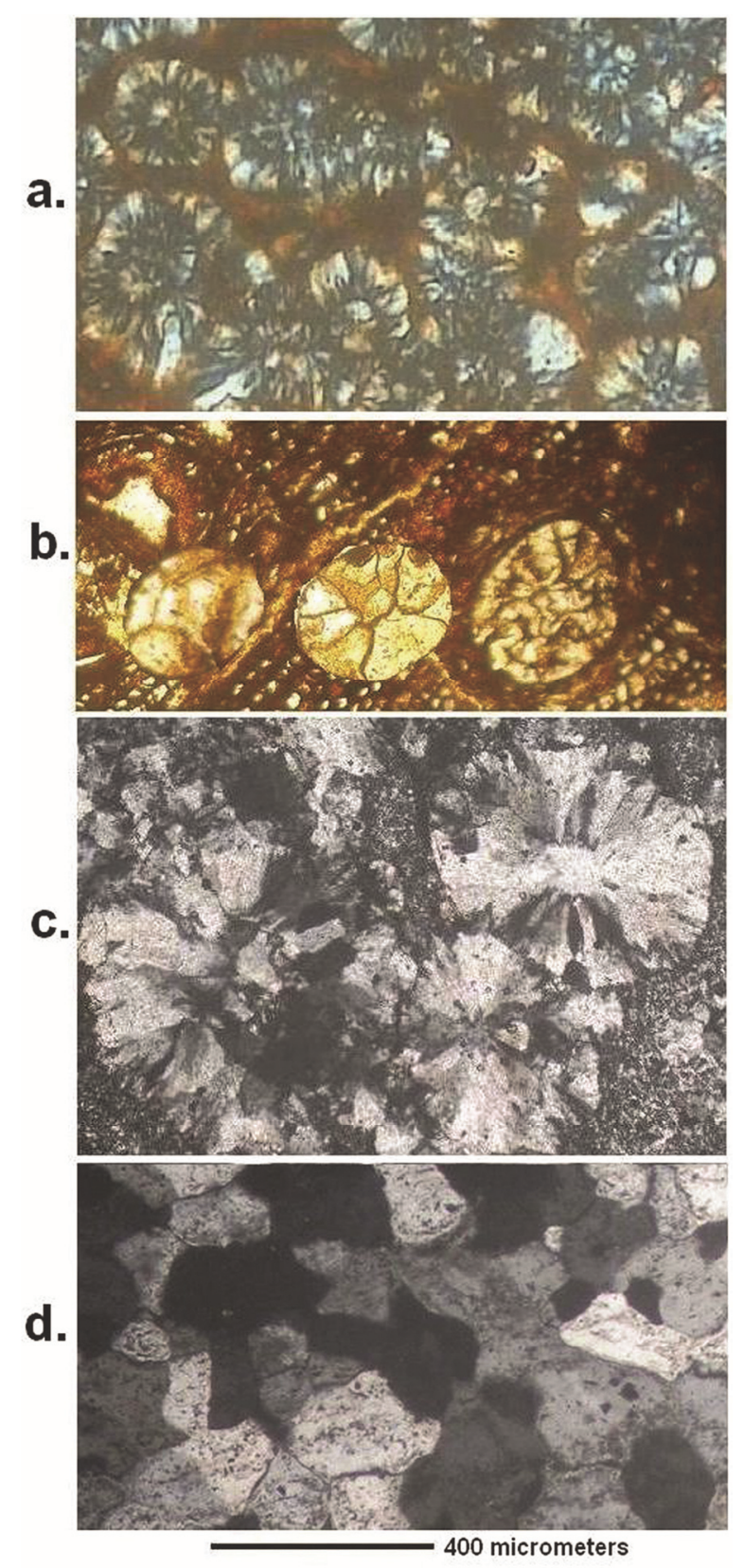

Fig. 6. Optical micrographs taken under cross polars: (a) transverse view of S1 showing relics of cubic cells filled with chalcedony, producing a dense or lepisphere-type fabric. (b) Transverse view of S2 revealinng elliptical cell structures with chalcedony-goethite fibres. (c) Fan-like forms of quartz in chalcedony matrix in sample S5. (d) Microgranular grains of quartz in petrified wood in sample S10. Note that (1) the reddish- and brown colors in S1 and S4 are mainly due to iron inclusions and (2) the dark areas in both S5 and S10 are due to the complete extinction of quartz or chalcedony. 
have been formed as primary phases under different pore-fluid pressures and silica concentrations (Buurman 1972; Jefferson, McDonald 1981). Mustoe (2008) concluded that "under epithermal conditions, opal is precipitated when concentrations of dissolved silica are relatively high, but lower silica concentrations may result in direct precipitation of chalcedony" (Mustoe 2008, p. 138). Quartz precipitates only from solutions that are extremely diluted in silica (Iler 1979; Fournier 1985).

\section{Conclusion}

Some fossil wood samples collected from the New Cairo Petrified Forest are petrified with chalcedony, others with a combination of chalcedony and quartz, and still others with quartz. An opaline precursor to the chalcedony and quartz may or may not have existed. The crystallinity index of the quartz determined by XRD is consistent with the petrography. The major impurities found in the samples studied are goethite plus/or minus moganite. The absence of moganite in some samples may imply that either moganite had been transformed to quartz, or that it had been leeched out.

Acknowledgments. The author acknowledges A.S.E. Madden of the School of Geology and Geophysics, University of Oklahoma, Norman, USA for X-ray diffraction analyses. E.M. Abuzeid is also acknowledged for helping with optical-microscope analysis. Special thanks are due to D.S. Helman of Prescott College, Arizona, USA for suggestions and comments to the manuscript. Thanks are also due to the Editor-in-Chief (M. Michalik), Associate Editor (L. Marynowski), K. Szopa and one anonymous reviewer who helped bring this manuscript to a satisfactory level of clarity for publication in this Journal.

\section{References}

Buurman, P. (1972). Mineralization of fossil wood. Scripta Geologia, 12, 1-43.

El-Faramawi, M.W.A.K.I. (2008). Studies in the flora of the Cairo Petrified Forest. Ph.D. dissertation, Botany Department, Faculty of Sciences, Ain Shams University, Cairo, Egypt.

El-Saadawi, W., Kamal-El-Din, M.M., Attia, Y., \& El-Faramawi, M.W. (2011). The wood flora of the Cairo Petrified Forest, with five Paleogene new legume records for Egypt. Review of Palaeobotany and Palynology, $167,184-195$.

Fournier, R.O. (1985). The behavior of silica in hydrothermal solutions. In B.B. Berger \& P.M., Bethke (Eds.), Geology and geochemistry of epithermal systems. Reviews in Economic Geology, 2, 45-61.

Hassan, K.M. (2010). Valences and site characteristics of iron in radioactive magmatic veins (Egypt): A Mössbauer and chemical study. Mineralogia, 41(1-2), 23-33. DOI: 10.2478/v10002-010-0003-2.

Hassan, K.M. (2015a). The iron mineralogy of Eocene fossil wood - A Mössbauer study from the Petrified Forest, New Cairo, Egypt. Accepted, The Canadian Mineralogist.

Hassan, K.M. (2015b). Stable isotopic signatures of the modern land snail Eremina desertorum from a low-latitude (hot) dry desert - A study from the Petrified Forest, New Cairo, Egypt. Chemie der Erde - Geochemistry, 75(1), 65-72.

Hassan, K. M., \& Gunnlaugsson, H. P. (2013). Characterization of barren, granitic soils from the Nubian Desert (SW Egypt) by ${ }^{57}$ Fe Mössbauer spectroscopy. Mineralogia, 44(1-2), 39-51. DOI: 10.2478/mipo-2013-0004.

Hatipoğlu, M., \& N Türk, N. (2009). A combined polarizing microscope, XRD, SEM, and specific gravity study of the petrified woods of volcanic origin from the Camlıdere- 82 Celtikci-Gudul fossil forest, in Ankara, Turkey. Journal of African Earth Sciences, 53, 141-157. DOI 10.1016/j.jafrearsci.2009.01.001.

Heaney, P.J., \& Post, J.E. (1992). The widespread distribution of a novel silica polymorph in microcrystalline quartz varieties. Science, 255, 441-443. DOI: 10.1126/science.255.5043.441. 
Iler, R.K. (1979). The colloid chemistry of silica and silicates. New York: Wiley.

Jefferson, T.H., \& McDonald, D.I. (1981). Fossil wood from South Georgia. British Antarctic Survey Bulletin, 54, 57-64.

Murata, K.J. (1940). Volcanic ash as a source of silica for the silicification of wood. American Journal of Science, $238,586-596$

Murata, K.J., \& Norman, H. (1976). An index of crystallinity for quartz. American Journal of Science, 276, 11201130.

Mustoe, G.E. (2008). Mineralogy and geochemistry of late Eocene silicified wood from Florissant Fossil Formation Beds National Monument, Colorado. The Geological Society of America, Geological Society of America Special Papers, 2008, 435, 127-140. DOI: 10.1130/2008.2435(09).

Said, R. (1962). The Geology of Egypt. New York: Elsevier Publishing Company.

Said, R. (1990). The Geology of Egypt. Rotterdam, Brookfield: A. A. Balkema

Scurfield, G., \& Segnit, E.R. (1984). Petrification of wood by silica minerals. Sedimentary Geology, 39, 149-167.

Stein, C.I. (1982). Silica recrystallization of petrified wood. Journal of Sedimentary Petrology, 52, 1277-1281.

Sutherland, J. (1994). Some aspects of petrification of Miocene wood from Kaipara Harbour, New Zealand. Geoscience Reports of Shizuoka University, 20, 143-151. 